Finally in 1545 appeared 'The Primer eet foorth by the Kynges maiestie and his Clergie, to be tanght, lerned and read; and none other to be used throughout all his dominions.' In this there are only three invocetions of seints, vis.for vs.

Holy virgyn Mari, mother of God our saniour Jeana Chriet: Pray

All holy Angels and drohangels and al boly ordera of blewed spirites: Pray for $\mathbf{r a t}$.

All holy Patriarkes and Propheten, Apostles and Martyra, Confossours and virgyns, and al tho blesaed compeny of heaven: Pray for $\mathrm{rg}$.

But there is here nothing special for festival days.

JAYEB GLIRDNBR.

\title{
Il Schifanoya's Account of the Coronation of Queen Elisabeth.
}

Is the recent discuesion in this Review on the coronetion of Queen Elizebeth ${ }^{1}$ difficulties have arigen from the fact that the report by Il Schifanoya is given by NIr. Raweon Brown in the Venetian Caleadar' in the form only of an abstract. Mr. Wilson angs that Behifanoye doe not sem to know that the Epistle and Gospel were resd in Latin as well as in English, and he discredits the suggestion that there was no conecration of the Host; while Mr. Bayne explains this etatement by anying that the words mean that there nas no valid coneecration. It may therefore be of interest to give a transcript of the passage in question from the original doeument, in the Arantaan archives, side by side with Mr. Rawson Brown's tranalation :-

... et fa delli cantori comin. cirata lo Mouas, et cantate del decano delle sus capells, suo capelleno, non havendo voluto gli veseovi celebraro senze levare il corpo di Christo, ne consecrare l' hostis con lo perole Englesi, come fece quel baon homo, et fo detto l' Epistole et l' Evangaho in Englese doppo li cantati in latino.
... the choriutars commenoed the Mase, which wes rong by the doen of her chapel, her chaplain, the biabopa not heving chouen to ay Mase without elovating the Ho:t or consecrating it, as that worthy individanl did; the Epistle and Gospel being recitad in Engligh.

Here Schilanoya plainly states that the Epistle and Goepel were read both in Latin and in Engliah, and does not at all say that there was no consecration of the Host. It seems that the facts

$$
\text { 'Vol, xill p. 650, rol, sxill p. } 57 . \quad \text { Vol. nt. p. } 17 .
$$


were really as follows: What Elizabeth desired, and what the bishops refused to do, was, not that the coronation Mase should be said without any consecration, but that the words of consecrstion should be said in English.

G. Lockgart Rogs.

\section{Sir Sidney Smath and Frotte in 1796.}

Tys letter printed below is to be found among the Puisaye papers in the British Maseum (Add. Mf8. 8054. f. 185). It bears neither soperscription nor endorsement, and is signed only with $\mathrm{Bir}$ Sidney Smith's initials-W. B. S. The recipient is identified as (Captain) John Wesley Wright by the mention of his initisls in the text of the letter. ${ }^{1}$ The document, which was written only ten days before Bidney Smith'в capture off Harre on 19 April 1796, throws light on the movements of Wright, of whose proceedings during the previous two years with Bidney Smith in the "Diamond ' little is known-certainly not the fact that he, an Englishman, was sent as a secret agent to Frotté; and it supplies, more then conjecturally, the name of the correspondent to whom Protte wrote, at the beginning of April 1796, the letter, 'Au chevalier _- ,' of whose destination even M. de La Bicotière avors himself ignorant.' This letter of Frotte's, if read in the light of Sidney Smith's wish to meet him expresed in his commanication to Wright, can bcarcely lead to any other conclusion than that its intended recipient, the unnamed ' chevalier,' was the English captain bimself. The royalist general expresses his regrets :

de ne pouvoir, une foin a moins, pónétrer jusqu'd vous, en trevers de mew nombrew ennemis, oni, bien nombreux, Af. le chovalier . . . Vous etes un preax chevalier, et en vous je meto toate ma confienco. Veuillez bien m'informer, wec cotte franchine digne de voues de la marehe de la diplomutio.2

This procisely what Sidney Smith did, for Frotte prites to Puisaye on 9 Mry, that Windham a ou la bonte de ne faire dire par Sir Sidnoy Smith que l'on n'entrerait dare oucun arrangement ou négociation sans nous en prévenir. ${ }^{4}$ Frottó goes on to acknorledge the recaipt of a letter of 23 February from his correspondent, who must have given vent therein to a wish singulerly resembling Sidney Bmith's 'earnest desire' to shake hands with Frotte ' on the beech of the Cotentin, one side or other,' which he commissioned Wright to mention to him (below, p. 597), for Frotté replies, Vous desires mo

1 Ho res ratod at thle time as midehlpmen, and epperently performed the datien of eupten's obert. Drat of Nat. Brogr. lriii. 114.

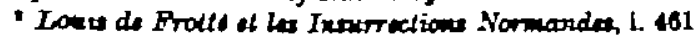

- Ibad.

1 Ibid. p. 019. 